\title{
Molecular and Serological Typing of Potato virus Y Isolates from Brazil Reveals a Diverse Set of Recombinant Strains
}

Suellen B. F. Galvino-Costa, Federal University of Lavras, Minas Gerais, Brazil and Department of PSES, University of Idaho, Moscow 83844; Antonia dos Reis Figueira, Federal University of Lavras; Francisco de Assis Câmara Rabelo-Filho, Universidade Estadual do Maranhão, Brazil; Flavio Henrique Reis Moraes, Universidade Federal Rural de Pernambuco, Brazil; and Olga V. Nikolaeva and Alexander V. Karasev, Department of PSES, University of Idaho

\begin{abstract}
Galvino-Costa, S. B. F., Figueira, A. R., Rabelo-Filho, F. A. C., Moraes, F. H. R., Nikolaeva, O. V., and Karasev, A. V. 2012. Molecular and serological typing of Potato virus $Y$ isolates from Brazil reveals a diverse set of recombinant strains. Plant Dis. 96:1451-1458.

In Brazil, Potato virus $Y$ (PVY) currently presents a significant problem for potato production, reducing tuber yield and quality. Recombinant tuber necrotic isolates of PVY had been reported to occur in the country but no systematic study of the PVY isolate diversity was conducted thus far. Here, a panel of 36 PVY isolates, randomly collected in Brazil from potato between 1985 and 2009, was subjected to a systematic molecular and serological typing using reverse-transcription polymerase chain reaction and a series of $\mathrm{PVY}^{\mathrm{O}}$ - and $\mathrm{PVY}^{\mathrm{N}}$-specific monoclonal antibodies. The data collected were combined with biological characterization of the same isolates in tobacco. Of the 36 isolates tested, 3 were typed as PVYO, 10 as PVY ${ }^{\mathrm{N}: \mathrm{O} / \mathrm{N}-\mathrm{Wi}}, 21$ as PVYNTN, and 2 as "unusual" or inconclusive. Of the 10 isolates from the recombinant PVY ${ }^{\mathrm{N}: \mathrm{O} / \mathrm{N}-\mathrm{Wi}}$ strain group, 1 isolate, MAF-VOY, was found to have an unusual serological profile identical to the nonrecombinant

isolate that did not induce vein necrosis in tobacco and 2 isolates with an unusual serological profile (i.e., displaying negative reactivity to one commercial $\mathrm{PVY}^{\mathrm{N}}$-specific monoclonal antibody). Whole genome sequences were determined for four PVY isolates from Brazil, representing $\mathrm{PVY}^{\mathrm{O}}, \mathrm{PVY}^{\mathrm{NTN}}$, and $\mathrm{PVY}^{\mathrm{N}-\mathrm{Wi}^{\mathrm{i}}}$ strains. The genome of the MAF-VOY isolate was found to be recombinant, having characteristic $\mathrm{N}-\mathrm{Wi}$ structure with two recombinant junctions and carrying a single mutation in the capsid protein at position 98 , which led to an unusual O5 serological reactivity. Taken together, the data obtained suggest that the two recombinant strains, $\mathrm{PVY} \mathrm{NTN}^{\mathrm{TN}}$ and $\mathrm{PVY}^{\mathrm{N}: \mathrm{O} / \mathrm{N}-\mathrm{Wi}}$, now are apparently dominant in the Brazilian potato crop. The data also suggest that recombinant isolates in Brazil often have unusual serological reactivity which may hamper their correct identification by conventional typing based on enzyme-linked immunosorbent assay.
\end{abstract} $\mathrm{PVY}^{\mathrm{O}}-\mathrm{O} 5$ strain group. The 21 tested $\mathrm{PVY}^{\mathrm{NTN}}$ isolates included 1
Potato virus $Y$ (PVY) is one of the most important pathogens in potato worldwide $(22,29)$. It affects potato tuber yield (44) and quality, inducing potato tuber necrotic ringspot disease (PTNRD), which makes tubers of susceptible cultivars unmarketable as fresh potato (4). PVY belongs to the genus Potyvirus, family Potyviridae, and, under natural conditions, is transmitted by more than 50 species of aphids in a nonpersistent manner (29).

Difficulties in managing PVY in potato and other crops susceptible to PVY (such as pepper, tomato, and tobacco) stem, to a large extent, from a huge diversity in PVY strains and multiple recombinant virus genomes. Five genetic strain groups of PVY were defined based on hypersensitive response reactions in a set of potato indicators carrying different $N$ resistance genes, and reactions in tobacco: these were $\mathrm{PVY}^{\mathrm{O}}, \mathrm{PVY}^{\mathrm{C}}, \mathrm{PVY}^{\mathrm{N}}, \mathrm{PVY}^{\mathrm{Z}}$, and $\mathrm{PVY}^{\mathrm{E}}(2,10,26,48)$. In addition to these genetic strains of PVY, multiple recombinants were found carrying segments of $P V Y^{\mathrm{O}}$ and $\mathrm{PVY}^{\mathrm{N}}$ genomes in various combinations. The most common recombinants found in Europe and North America were PVY ${ }^{\mathrm{N}: \mathrm{O}}$ (one recombinant junction $[R J]$ ), $\mathrm{PVY}^{\mathrm{N}-\mathrm{Wi}}$ (two RJs), and PVY ${ }^{\mathrm{NTN}}$ (three or four RJs) $(21,23)$. Additional recombinants and variants were reported, such as PVY ${ }^{\mathrm{NA}-\mathrm{N}}$ and PVY-NE-11 (32,33). Since about early 1980s, a transition was observed in Europe and elsewhere from predominantly nonrecombinant strains such as $\mathrm{PVY}^{\mathrm{O}}, \mathrm{PVY}^{\mathrm{C}}$, and $\mathrm{PVY}^{\mathrm{N}}$ to recombinant variants such as $\mathrm{PVY}^{\mathrm{NTN}}$ and $\mathrm{PVY}^{\mathrm{N}-\mathrm{Wi}} / \mathrm{PVY}^{\mathrm{N}: \mathrm{O}}$, often associated with PTNRD syndrome $(4,22,30)$. Changes in PVY strain composition had important con-

Corresponding author: A. V. Karasev, E-mail: akarasev@uidaho.edu

Accepted for publication 26 April 2012.

http://dx.doi.org/10.1094/PDIS-02-12-0163-RE

(C) 2012 The American Phytopathological Society sequences for the potato industry in all countries affected by PVY, leading to changes in potato certification systems and complete removal from production of potato cultivars susceptible to PTNRD.

To distinguish PVY strain groups and variants, several approaches can be utilized. In addition to the potato indicator test, reactions in tobacco are often used to broadly divide PVY isolates into those inducing vein necrosis and those inducing only mosaic and vein clearing. Isolates inducing vein necrosis in tobacco generally belong to the $\mathrm{PVY}^{\mathrm{N}}$ strain group, or have recombinant genomes, such as PVY ${ }^{\mathrm{NTN}}, \mathrm{PVY}^{\mathrm{N}-\mathrm{Wi}}$, or $\mathrm{PVY}^{\mathrm{N}: \mathrm{O}}$. Nevertheless, recently, $\mathrm{PVY}^{\mathrm{Z}}$ and $\mathrm{PVY}^{\mathrm{E}}$ strain groups were demonstrated to have recombinant genomes, and some isolates from these strain groups were found to be non-necrotic in tobacco $(19,24,30)$. Two basic laboratory approaches are also used to distinguish PVY strain groups and variants: serology with $\mathrm{PVY}^{\mathrm{N}}$ - and $\mathrm{PVY}^{\mathrm{O}}$-specific monoclonal antibodies (MAbs) (12,28), and reverse-transcription polymerase chain reaction (RT-PCR) methodology utilizing nucleotide polymorphism characteristic of specific PVY strains and recombinant variants $(6,8,34)$. Tremendous diversity in PVY strains and rapid evolution of the virus through recombination and mutations created an interesting situation where no single method of PVY strain differentiation is sufficient to type a field isolate of PVY, and multiple methods are necessary to confidently assign such an isolate to a particular strain group (22).

In South America, PVY was first described in the early 1940s; however, it was not considered a problem for potato production in Brazil at that time (43). Until the early 1990s, PVY was rarely detected in the Brazilian potato fields and the Potato leafroll virus was considered, for a long time, to be the only potato virus related to yield losses. Nevertheless, between 1985 and 1987, sporadic PVY outbreaks were recorded in some experimental fields with the extremely susceptible cultivar 'Chiquita', located at Minas Gerais State. At that time, the majority of PVY isolates were assumed to represent $\mathrm{PVY}^{\mathrm{O}}$, because they did not induce vein necrosis in 
tobacco, and only a few of them were characterized as necrotic isolates, based on the vein necrosis in tobacco $(17,18)$. However, about a decade later, the Brazilian potato growers started to report disease symptoms associated with tobacco necrotic PVY isolates in the commercial potato fields, especially in the fields planted with imported seed $(15,50)$. These necrotic PVY isolates apparently spread quickly and, in 1996, several Brazilian states reported problems in potato related to PVY. It is not clear whether any of the isolates causing vein necrosis in tobacco, described during this early PVY history in Brazil, belonged to the recombinant PVY strains or the nonrecombinant $\mathrm{PVY}^{\mathrm{N}}$ strain. Hence, the first official evidence of the presence of PVY ${ }^{\mathrm{N}-\mathrm{Wi}}$ and PVY ${ }^{\mathrm{NTN}}$ recombinant strains in Brazil was reported by two different laboratories, independently, in 1997, both in potato seed increases derived from seed potato imported from Europe or North America $(37-39,49)$. Currently, PVY ${ }^{\mathrm{NTN}}$ and $\mathrm{PVY}^{\mathrm{N}-\mathrm{Wi}}$ have been reported to be the predominant PVY recombinant strains in potato in almost all Brazilian states $(1,7,13,45,46)$. Nevertheless, only a limited set of tools was applied to PVY isolate characterization in Brazil thus far, and the molecular, serological, and biological diversity among the PVY isolates circulating in Brazil in potato crops was not studied on a systematic basis up until very recently (19).

A recent initial systematic study of just three recombinant PVY isolates collected from potato in 2008 demonstrated the occurrence of a rare $\mathrm{PVY}^{\mathrm{E}}$ genetic strain in Brazil, and an unusual serological profile or recombinant structure characteristic of $\mathrm{PVY}^{\mathrm{E}}$ and PVY $^{\text {NTN }}$ isolates circulating in Brazilian potato (19). These initial findings suggested a substantial diversity among potato PVY isolates in Brazil and circulation of rare and unusual types of PVY recombinants, and prompted our study of a larger set of 36 PVY isolates collected from field potato and maintained in the Plant Pathology Laboratory in the Federal University of Lavras, Minas
Gerais, Brazil. Here, we describe the diversity of potato PVY isolates having circulated in Brazil over a span of 24 years, from 1985 to 2009 , using a combination of biological, serological, and molecular techniques. The data obtained suggested a large diversity of recombinant PVY isolates circulating in Brazil, and allowed us to speculate on an approximate history of changes in PVY strain composition in potato in Brazil between 1985 and 2009. This is the first comprehensive study of potato isolates of PVY conducted on 36 random field samples.

\section{Materials and Methods}

Virus isolates: origin and maintenance. The 36 Brazilian PVY isolates studied were collected between 1985 and 2009. All PVY isolates were initially collected by seed potato growers who submitted tubers for post-harvest testing to the enzyme-linked immunosorbent assay (ELISA) Laboratory (Centro de Indexação de Virus-CIV/MG) at the Federal University of Lavras, and, thus, were considered random samples. The majority of the samples, 33, came from the state of Minas Gerais, where the main production of Brazilian potato occurs; however 2 samples were received from São Paulo, and 1 sample from Paraná. Locations of the initial field collections and potato cultivars where these isolates originated are listed in Table 1. The infected tubers were transplanted to pots in an insect-proof greenhouse, and emerging plants were tested serologically for four potato viruses (PVY, Potato leafroll virus, Potato virus $S$, and Potato virus $X$ ) and confirmed to be infected only with PVY. Tubers obtained from these original infected potato plants were stocked and had been periodically multiplied to maintain the original inoculum. Potential PVY strain mixtures were detected using either strain-specific triple-antibody sandwich (TAS)-ELISA (28) or the standard RT-PCR assay according to Lorenzen et al. (34). The standard PVY isolates Tb60 and $\mathrm{Oz}\left(\mathrm{PVY}^{\mathrm{O}}\right)$, ID269

Table 1. List of Potato virus $Y$ isolates studied, grouped according to the year of collection ${ }^{\text {a }}$

\begin{tabular}{|c|c|c|c|}
\hline Isolate ID & Year collected & Cultivar & Location (city/state) \\
\hline YO-ANT25 & 1985 & Achat & Maria da Fe/Minas Gerais \\
\hline YN-UFLA\#1 & 1987 & Unknown & Southern Minas Gerais \\
\hline YN-UFLA\#2 & 1987 & Unknown & Southern Minas Gerais \\
\hline PVY-FORTE & 1996 & Baraka & Maria da Fe/Minas Gerais \\
\hline Y-BR & 1996 & Achat & Itajubá/Minas Gerais \\
\hline YN-IBIA & 1997 & Monalisa & Ibiá/Minas Gerais \\
\hline YN-SP22 & 1999 & Jaette Bintje & Jose Furtado/Sao Paulo \\
\hline YN-VELOX & 1999 & Velox & Três Coracões/Minas Gerais \\
\hline YO-SP08 & 1999 & Bintje & São Paulo \\
\hline $\mathrm{PVY}^{\mathrm{N}}-\mathrm{MG}$ & 1999 & Bintje & Tiros/Minas Gerais \\
\hline Y-BR2 & 2000 & Achat & Itajubá/Minas Gerais \\
\hline SGS-AG & 2007 & Agata & São Goncalo Sapucai/Minas Gerais \\
\hline ALF-VI & 2007 & Vivaldi & Alfenas/Minas Gerais \\
\hline ARA-MO & 2007 & Monalisa & Araxá/Minas Gerais \\
\hline TAP-AG & 2007 & Agata & Tapira/Minas Gerais \\
\hline COR-AG & 2007 & Agata & Coromandel/Minas Gerais \\
\hline IPU-MA & 2007 & Markies & Ipuiúna/Minas Gerais \\
\hline LAV-CL & 2007 & Unknown & Lavras/Minas Gerais \\
\hline MFE-AG & 2007 & Agata & Maria da Fe/Minas Gerais \\
\hline SGS-MO & 2008 & Monalisa & São Goncalo Sapucaí/Minas Gerais \\
\hline MF-AST & 2008 & Asterix & Maria da Fé/Minas Gerais \\
\hline PA2-AGA & 2008 & Agata & Pouso Alegre/Minas Gerais \\
\hline LA-MON & 2008 & Monalisa & Lavras/Minas Gerais \\
\hline ES-AGA & 2008 & Agata & Estiva/Minas Gerais \\
\hline SA-AST & 2008 & Asterix & Senador Amaral/Minas Gerais \\
\hline MU-AGA & 2008 & Agata & Muzambinho/Minas Gerais \\
\hline LUI-AGA & 2009 & Agata & Luiziana/Parana \\
\hline PEN-AG2 & 2009 & Agata & Pedrinópolis/Minas Gerais \\
\hline PED-AX & 2009 & Asterix & Pedralva/Minas Gerais \\
\hline MAF-CA & 2009 & Caesar & Maria da Fe/Minas Gerais \\
\hline PED-CA & 2009 & Caesar & Pedralva/Minas Gerais \\
\hline CRI-AX & 2009 & Asterix & Cristina/Minas Gerais \\
\hline MAF-VOY & 2009 & Voyager & Maria da Fé/Minas Gerais \\
\hline DOV-AG & 2009 & Agata & Dom Viçoso/Minas Gerais \\
\hline PED-AG & 2009 & Agata & Pedralva/Minas Gerais \\
\hline MAF-VIV & 2009 & Vivaldi & Maria da Fé/Minas Gerais \\
\hline
\end{tabular}

a Potato cultivars from which the isolate was collected and location of the initial collection are also listed. 
(PVYO-O5), Mont $\left(\mathrm{PVY}^{\mathrm{N}}\right), 423-3, \mathrm{~N} 4$, and L26 (all PVY ${ }^{\mathrm{NTN}}$ ), and PVY-NE-11 used for comparisons were from the University of Idaho Plant Virology Laboratory collection $(24,28,33)$.

Biological characterization in tobacco. To investigate the pathotype of Brazilian isolates, 'Burley' and 'Samsun' tobacco were used. In each experiment, four plants per isolate were inoculated, and testing was repeated three times for each isolate. All plants were mechanically inoculated at a four- to six-leaf stage as described previously (24). Control PVY isolates from the laboratory collection were always included in the experiment. Visual scoring of PVY symptoms in tobacco commenced 5 days post inoculation (dpi) and continued for 4 to 5 weeks. Each plant was scored daily for visual symptoms starting at $5 \mathrm{dpi}$, and later tested by TAS-ELISA and RT-PCR in order to confirm the PVY infection status and to type the PVY isolate infecting the specific plant. All plants were grown in an insect-proof greenhouse before and after inoculations under natural light supplemented by fluorescent and incandescent lamps with a day-and-night cycle of 18 and $6 \mathrm{~h}$, respectively, and maintained at 24 to $26^{\circ} \mathrm{C}$ (day) and 16 to $18^{\circ} \mathrm{C}$ (night) throughout the experiment.

Serological analysis. The serological reactivity of PVY isolates was tested in a TAS-ELISA format, as described by Karasev et al. (28). All tests included control PVY isolates from the laboratory collection, displaying distinct serological patterns characteristic of $\mathrm{PVY}^{\mathrm{O}}, \mathrm{PVY}^{\mathrm{N}}$, and $\mathrm{PVY}{ }^{\mathrm{O}}-\mathrm{O} 5$ strain groups. In addition to a polyclonal antiserum (28), three strain-specific MAbs were used: $\mathrm{MAb} 2$ recognizing $\mathrm{PVY}^{\mathrm{O}}, \mathrm{PVY}^{\mathrm{O}}-\mathrm{O} 5, \mathrm{PVY}^{\mathrm{N}-\mathrm{Wi} / \mathrm{N}: \mathrm{O}}$, and $\mathrm{PVY}^{\mathrm{C}}(35)$
(Agdia); 1F5 recognizing $\mathrm{PVY}^{\mathrm{N}}, \mathrm{PVY}^{\mathrm{O}}-\mathrm{O} 5$, and $\mathrm{PVY}^{\mathrm{NTN}}$ $(12,28,42)$ (Agdia); and SASA-N recognizing $\mathrm{PVY}^{\mathrm{N}}$ and $\mathrm{PVY}^{\mathrm{NTN}}$ (42) (Scottish Agriculture Science Agency).

RT-PCR and differentiating primers. To classify all 36 isolates, and check for possible mixed infections, a multiplex assay described by Lorenzen et al. (34) was used. In this assay, eight primers are combined in a single multiplex RT-PCR test to differentiate $\mathrm{PVY}^{\mathrm{O}}, \mathrm{PVY}^{\mathrm{N}}, \mathrm{PVY}^{\mathrm{N}: \mathrm{O} / \mathrm{N}-\mathrm{Wi}}, \mathrm{PVY}^{\mathrm{NTN}}$, and $\mathrm{PVY}^{\mathrm{NA}-\mathrm{N}}$, or mixtures of those. An additional primer pair was used to differentiate $\mathrm{PVY}^{\mathrm{E}}$ genome from PVY-NE-11 and ordinary PVY ${ }^{\mathrm{NTN}}$ isolates, as described elsewhere (19). Virus RNA extraction and the multiplex RT-PCR assay were performed as described (34). About $100 \mathrm{mg}$ of tobacco leaf tissue was homogenized using a mini-pestle in an Eppendorf tube containing $400 \mu \mathrm{l}$ of fresh extraction buffer (Dellaporta I: $100 \mathrm{mM}$ Tris [pH 8.0], $50 \mathrm{mM}$ EDTA, 500 $\mathrm{mM} \mathrm{NaCl}$, and $10 \mathrm{mM} 2$-mercapto-ethanol); then, $52.8 \mu \mathrm{l}$ of $10 \%$ sodium dodecyl sulfate (SDS) was added, followed by vortexing and incubating at $65^{\circ} \mathrm{C}$ for $10 \mathrm{~min}$. After the addition of $128 \mu \mathrm{lof}$ $5 \mathrm{M}$ potassium acetate, the mixture was vortexed and subjected to low-speed centrifugation for $10 \mathrm{~min}$. The resulting supernatant was carefully removed and nucleic acids precipitated with isopropanol. The pellet was washed twice in $70 \%$ ethanol, air dried, and resuspended in $80 \mu \mathrm{l}$ of diethylpyrocarbonate-treated water. Reverse transcription was performed using $1 \mu \mathrm{l}$ of the total nucleic acid extract in a $15-\mu$ reaction volume that contained $5 \times$ first-strand buffer (Invitrogen), $1 \mathrm{mM}$ (each) dNTP, $0.12 \mu \mathrm{M}$ oligo-dT primer mix, 6 units of RNase Out Ribonuclease Inhib-

Table 2. Summary of biological, serological, and molecular typing of the 36 Brazilian isolates studied

\begin{tabular}{|c|c|c|c|c|c|c|}
\hline \multirow[b]{2}{*}{ Isolate ID } & \multirow[b]{2}{*}{ Symptoms ${ }^{b}$} & \multicolumn{3}{|c|}{ Serology ${ }^{a}$} & \multirow[b]{2}{*}{ RT-PCR $^{\mathrm{c}}$} & \multirow[b]{2}{*}{ Final call } \\
\hline & & MAb2 & $1 F 5$ & SASA-N & & \\
\hline YO-ANT25 & $\mathrm{M}$ & + & - & - & $\mathrm{O}$ & $\mathrm{O}$ \\
\hline YN-UFLA\#1 & SM & + & - & - & NA-N & $?$ \\
\hline YN-UFLA\#2 & FM & + & - & - & $\mathrm{O}$ & $\mathrm{O}$ \\
\hline PVY-FORTE & $\mathrm{VN}$ & - & + & + & NTN & NTN \\
\hline Y-BR & SM & + & - & - & NA-N/O & $?$ \\
\hline YN-IBIA & VN & - & + & + & NTN & NTN \\
\hline YN-SP22 & VN & - & + & + & NTN & NTN \\
\hline YN-VELOX & VN & - & + & + & NTN & NTN \\
\hline YO-SP08 & $\mathrm{M}$ & + & - & - & $\mathrm{O}$ & $\mathrm{O}$ \\
\hline $\mathrm{PVY}^{\mathrm{N}}-\mathrm{MG}$ & VN & - & + & + & NTN & NTN \\
\hline Y-BR2 & VN & + & - & - & $\mathrm{N}: \mathrm{O}$ & $\mathrm{N}: \mathrm{O} / \mathrm{N}-\mathrm{Wi}$ \\
\hline SGS-AG & VN & + & - & - & $\mathrm{N}: \mathrm{O}$ & N-Wi \\
\hline ALF-VI & VN & - & + & + & NTN & NTN \\
\hline ARA-MO & VN & - & + & + & NTN & NTN \\
\hline TAP-AG & $\mathrm{VN}$ & - & + & + & NTN & NTN \\
\hline COR-AG & VN & - & + & + & NTN & NTN \\
\hline IPU-MA & $\mathrm{VN}$ & - & + & + & NTN & NTN \\
\hline LAV-CL & FM & + & - & - & $\mathrm{N}: \mathrm{O}$ & $\mathrm{N}: \mathrm{O} / \mathrm{N}-\mathrm{Wi}$ \\
\hline MFE-AG & VN & + & - & - & $\mathrm{N}: \mathrm{O}$ & $\mathrm{N}: \mathrm{O} / \mathrm{N}-\mathrm{Wi}$ \\
\hline SGS-MO & $\mathrm{VN}$ & - & + & - & NTN & NTN/AST \\
\hline MF-AST & M & - & + & + & NTN & NTN/Z \\
\hline PA2-AGA & VN & - & + & + & NTN & NTN \\
\hline LA-MON & $\mathrm{VN}$ & - & + & + & NTN & NTN \\
\hline ES-AGA & VN & - & + & + & NTN & NTN \\
\hline SA-AST & $\mathrm{VN}$ & - & + & + & NTN & NTN \\
\hline MU-AGA & VN & - & + & - & NTN & NTN/AST \\
\hline LUI-AGA & VN & - & + & + & NTN & NTN \\
\hline PEN-AG2 & $\mathrm{VN}$ & - & + & + & NTN & NTN \\
\hline PED-AX & VN & + & - & - & $\mathrm{N}: \mathrm{O}$ & $\mathrm{N}: \mathrm{O} / \mathrm{N}-\mathrm{Wi}$ \\
\hline MAF-CA & VN & + & - & - & $\mathrm{N}: \mathrm{O}$ & $\mathrm{N}: \mathrm{O} / \mathrm{N}-\mathrm{Wi}$ \\
\hline PED-CA & VN & + & - & - & $\mathrm{N}: \mathrm{O}$ & $\mathrm{N}: \mathrm{O} / \mathrm{N}-\mathrm{Wi}$ \\
\hline CRI-AX & VN & - & + & + & NTN & NTN \\
\hline MAF-VOY & VN & + & + & - & $\mathrm{N}: \mathrm{O}$ & N-Wi/O5 \\
\hline DOV-AG & VN & + & - & - & $\mathrm{N}: \mathrm{O}$ & $\mathrm{N}: \mathrm{O} / \mathrm{N}-\mathrm{Wi}$ \\
\hline PED-AG & VN & - & + & + & NTN & NTN \\
\hline MAF-VIV & $\mathrm{VN}$ & + & - & - & $\mathrm{N}: \mathrm{O}$ & $\mathrm{N}: \mathrm{O} / \mathrm{N}-\mathrm{Wi}$ \\
\hline
\end{tabular}

${ }^{a}$ Serological reactivity in triple-antibody sandwich enzyme-linked immunosorbent assay when the listed monoclonal antibodies (MAbs) were used as detecting antibodies.

b Tobacco reaction in 'Burley' and 'Samsun': $\mathrm{M}=$ mosaic/vein clearing and $\mathrm{VN}=$ vein necrosis; intensity of mosaic reaction: $\mathrm{F}=$ faint, $\mathrm{M}=$ regular, and $\mathrm{S}=$ severe.

${ }^{\mathrm{c}}$ Reverse-transcription polymerase chain reaction (RT-PCR) typing was conducted according to Lorenzen et al. (34). 
itor (Invitrogen), and 60 units of SuperScript II reverse transcriptase (Invitrogen).

Sequencing and sequence analysis. The whole-genome sequences were obtained by sequencing RT-PCR products for $\mathrm{Y}^{\mathrm{O}}$ ANT, ALF-VI, SGS-AG, and MAF-VOY isolates representing $\mathrm{PVY}^{\mathrm{O}}, \mathrm{PVY}^{\mathrm{NTN}}$, and $\mathrm{PVY}^{\mathrm{N}-\mathrm{Wi}}$ types, respectively, found in Brazil. The sequencing was conducted essentially as described by $\mathrm{Hu}$ et al. (24). Some additional primers were designed to complete the genome sequences of MAF-VOY and $\mathrm{Y}^{\mathrm{O}}$-ANT. All PCR products were purified using the ExoSAP-IT for PCR Product Clean-Up (USB Products; Affymetrix Inc.), mixed with appropriate primers and submitted for sequencing to Genewiz. The contigs obtained were assembled using the Lasergene Core Suite Software (DNASTAR), and the full-length sequences assembled were aligned using the CLUSTALW2 program with default settings. The
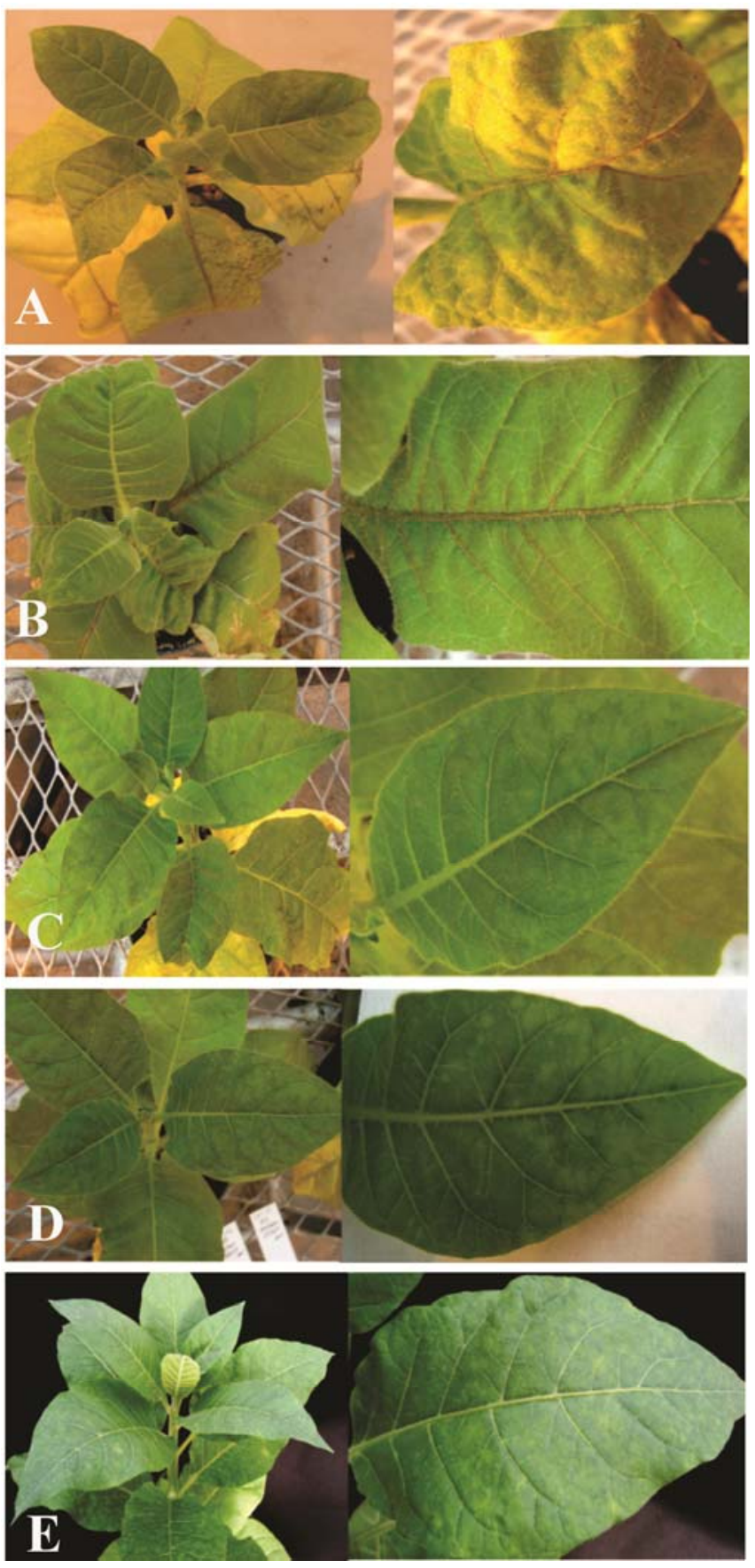

Fig. 1. Symptoms induced by five Brazilian isolates in tobacco ('Samsun'). A, MAFVOY (Potato virus Y [PVY] $]^{\mathrm{N}-W i}$-05); B, TAP-AG (PVYNTN); C, YO-SP08 (PVYO); D, LAV-CL (PVYN:O -minus); and E, MF-AST (PVYZ-NTN). sequence analysis and generation of phylogenetic trees were performed as described previously by Karasev et al. (27), and the recombination analysis as described by Galvino-Costa et al. (19) using the RDP4 package.

\section{Results}

Biological characterization in tobacco. All 36 isolates were tested in two tobacco cultivars, Burley and Samsun, following mechanical inoculation at the four- to six-leaf stage. Symptoms were consistent between Burley and Samsun, and both the type of symptoms and timing of their appearance were very similar for each isolate. Seven of the isolates tested induced vein clearing, various degree of mosaic, and leaf mottling but no vein necrosis (Table 2). On the other hand, 29 of the isolates induced vein necrotic reaction in both tobacco cultivars, sometimes visible in just 5 to $7 \mathrm{dpi}$, in addition to the vein clearing and mosaic. This vein necrosis generally coincided with stunting, sometimes very severe, and often with stem necrosis. If a younger plant was inoculated, at a four-leaf stage, it was completely necrotized and dead at about 10 dpi. Each plant was scored for visual symptoms and later tested by TAS-ELISA and RT-PCR in order to confirm the PVY infection status, and to type the PVY isolate infecting the specific plant. No inconsistencies or cross-contaminations were identified for more than 430 inoculated tobacco plants. In just a few cases, inoculations failed, and these plants were excluded from further experiments.

Serology of the Brazilian isolates. Serological typing of the Brazilian isolates under study is summarized in Table 2. Of the 36 isolates analyzed, 15 reacted with the $\mathrm{PVY}^{\mathrm{O}}$-specific antibody $\mathrm{MAb} 2$ and, thus, were typed as having the $\mathrm{PVY}^{\mathrm{O}}$ serotype. In all, 22 isolates reacted positively to the PVY ${ }^{\mathrm{N}}$-specific MAb 1F5, and 19 of these were also positive against another PVY ${ }^{\mathrm{N}}$-specific MAb, SASA-N. One of the 1F5-positive isolates, MAF-VOY, was also positive against $\mathrm{PVY}^{\mathrm{O}}$-specific MAb2 and negative against $\mathrm{MAb}$ SASA-N; thus, it was typed as having a characteristic PVY ${ }^{\mathrm{O}}-\mathrm{O} 5$ serotype (28). Two other 1F5-positive isolates, SGS-MO and MUAGA, did not bind the second $\mathrm{PVY}^{\mathrm{N}}$-specific antibody, SASA-N, while being MAb2 negative; this identified both isolates as having a characteristic PVY-AST serotype, as described elsewhere (19). In summary, 14 isolates were typed as having $\mathrm{PVY}^{\mathrm{O}}$ serotype, 1 was typed as $\mathrm{PVY}^{\mathrm{O}}-\mathrm{O} 5$, and 21 isolates as having broadly defined $\mathrm{PVY}^{\mathrm{N}}$ serotype (i.e., MAb2-negative, 1F5-positive, SASA-N-positive or negative; Table 2).

Molecular typing by RT-PCR. The 36 isolates were typed using the multiplex assay developed by Lorenzen et al. (34) which can distinguish between main recombinant and nonrecombinant potato PVY strain groups and their mixtures. The summary of this RT-PCR typing is presented in Table 2. In total, 3 isolates were typed as nonrecombinant $\mathrm{PVY}^{\mathrm{O}}$ type, 1 as $\mathrm{PVY}^{\mathrm{NA}-\mathrm{N}}$ type, 10 as recombinant $\mathrm{PVY}^{\mathrm{N}: \mathrm{O}}$ type, 21 as recombinant $\mathrm{PVY} \mathrm{Y}^{\mathrm{NTN}}$ type, and 1 (Y-BR) as an unusual type. This unusual RT-PCR profile included only one of the two bands characteristic of $\mathrm{PVY}^{\mathrm{O}}$, and the PVY $\mathrm{PA}^{\mathrm{NA}}$ band; in this case, the possibility of mixed infection was excluded, or at least greatly reduced, based on the clear $\mathrm{PVY}^{\mathrm{O}}$ serological typing for this isolate. To help further type this isolate, Y-BR, we used individual primer pairs designed to type $\mathrm{PVY}^{\mathrm{O}}$ and $\mathrm{PVY} \mathrm{Y}^{\mathrm{NA}-\mathrm{N}}$ in four different PCR assays (34). In the first assay, the isolate was tested using a single primer pair specific to PVY $^{\mathrm{NA}-\mathrm{N}}$ (n_5707+A6032m), which consistently amplified a characteristic NA-N band (328 bp) and, in the second assay, two specific PVY primer pairs (S5585m+o6266c and o2172+o2439) were used separately, with only o2172+o2439 primers generating one band (267 $\mathrm{bp)}$ characteristic of $\mathrm{PVY}^{\mathrm{O}}$. Thus, the primer pair responsible for amplification of the larger band, 689 bp (S5585m+o6266c) characteristic of the $\mathrm{PVY}^{\mathrm{O}}$ sequence, consistently failed to produce the respective amplicon for Y-BR in RT-PCR.

Isolate MAF-VOY, which was found to induce vein necrosis in tobacco (Fig. 1) and to have a characteristic PVY ${ }^{\mathrm{O}}$-O5 serotype (Table 2), was identified as a typical $\mathrm{N}: \mathrm{O}$ recombinant producing 181- and 689-bp bands (Fig. 2). No evidence of mixed infection 
was found during either RT-PCR typing in multiplex assay of Lorenzen et al. (34) (Fig. 2) or serological typing with $\mathrm{PVY}^{\mathrm{N}}$ - and $\mathrm{PVY}^{\mathrm{O}}$-specific MAbs. This RT-PCR typing was consistent with MAF-VOY's ability to induce vein necrosis in tobacco; however, this $\mathrm{N}: \mathrm{O}$ type of recombinant genome was not associated with the $\mathrm{PVY}^{\mathrm{O}}$-O5 serological marker before.

Whole-genome sequences. The entire genome was sequenced for four Brazilian isolates representing main PVY strains found in Brazil. The sequences of the $\mathrm{Y}^{\mathrm{O}}$-ANT $(9,649$ nucleotides [nt]), ALF-VI (9,698 nt), SGS-AG (9,674 nt), and MAF-VOY (9,691 nt) were deposited in the GenBank database and would appear under accession numbers JQ924285, JQ924287, JQ924288, and JQ924286, respectively. The four Brazilian whole-genome sequences were subjected to a phylogenetic analysis against 45 fulllength PVY sequences from the GenBank, including all major strains of PVY (Fig. 3). As expected, the four Brazilian isolates studied here clustered into the respective strain groups, with isolate ALF-VI grouped in the same branch as PB312, PVY-AST, HunNTN, 423-3, and other typical PVY ${ }^{\text {NTN }}$ isolates from GenBank (approximately 99\% identity). Similarly, MAF-VOY and SGS-AG isolates clustered into the $\mathrm{PVY} \mathrm{Y}^{\mathrm{N}-\mathrm{Wi}}$ group and $\mathrm{Y}^{\mathrm{O}}$-ANT clustered into the $\mathrm{PVY}^{\mathrm{O}}$ group. The $\mathrm{Y}^{\mathrm{O}}$-ANT isolate displayed $98 \%$ identity with PB-Oz and SCRI-O, both typical PVYO isolates.

The RDP analysis showed that isolate ALF-VI had a regular PVY $^{\text {NTN }}$ genome with the typical three RJs located at HC-Pro/P3, $\mathrm{CI} / \mathrm{NIa}$, and CP/3'UTR, at positions 2,413, 5,827, and 9,173, respectively, in the parental genome of isolate Mont. Positions of these RJs were very close to the position of RJs in the reference PVY ${ }^{\text {NTN }}$ isolate 423-3 (32). SGS-AG and MAF-VOY had the $\mathrm{PVY}^{\mathrm{N}-\mathrm{Wi}}$ genome with two RJs (at P1 and HC-Pro/P3). Positions of these RJs in the SGS-AG genome, at nucleotides 462 and 2,356 in the parental genome of isolate Mont, were almost identical to the reference $\mathrm{PVY} \mathrm{N}^{\mathrm{N}-\mathrm{Wi}}$ isolate $\mathrm{PN} 10 \mathrm{~A}$ (32) whereas, in the genome of MAF-VOY, positions of RJs at nucleotides 479 and 2,303 were shifted relative to the reference $\mathrm{PVY}^{\mathrm{N}-\mathrm{Wi}}$ isolate PN10A (32). In all three cases, $\mathrm{PVY}^{\mathrm{N}}$ (Mont) and $\mathrm{PVY}^{\mathrm{O}}$ (PB-Oz) were easily identified as parents of ALF-VI, SGS-AG, and MAF-VOY. The analysis also showed that the genome of $\mathrm{Y}^{\mathrm{O}}$-ANT was nonrecombinant and belonged to the PVY ${ }^{\mathrm{O}}$ strain group. Although both SGS-AG and MAF-VOY shared the same recombinant genomic structure, MAFVOY had a single amino acid substitution located at the 98th position of the coat protein (Q instead of R) (28), which explained the unusual $\mathrm{O} 5$ serotype identified in this $\mathrm{N}-\mathrm{Wi}$ isolate by TAS-ELISA (Table 2).

\section{Discussion}

Brazil is one of the largest producers of ware potato in South America; however, it is currently dependent on seed potato importation necessary for subsequent multiplication and propagation in certified seed potato fields. Large volumes of imported potato seed may certainly carry a risk of introduction of potato pathogens, including the new recombinant PVY strains. The main sources of seed potato imported by Brazilian producers are located in Europe, Canada, and the United States $(14,16)$, where a wide range of PVY types have been reported since the 1980s (2-4,9,20,21,23, $31,32,36,40,41,47)$. Recently, it was shown that the PVY isolates in Brazil were dominated by recombinant strains PVY ${ }^{\mathrm{NTN}}$ and $\mathrm{PVY}^{\mathrm{N}-\mathrm{Wi}}(1)$, similarly to what was reported in Europe and North Africa $(5,11)$. In particular, PVY ${ }^{\mathrm{NTN}}$ was found to be the most frequent among these recombinant strains, in at least seven different states of Brazil (1). Galvino-Costa et al. (19) reported on a rare $\mathrm{PVY}^{\mathrm{E}}$ strain found in two States in Brazil, and on an unusual serological profile characteristic of two isolates from $\mathrm{PVY}^{\mathrm{E}}$ and PVY ${ }^{\text {NTN }}$ strains. However, the presence of other PVY strains and variants, such as PVY ${ }^{\mathrm{N}: \mathrm{O}}, \mathrm{PVY}^{\mathrm{Z}}, \mathrm{PVY}^{\mathrm{O}}-\mathrm{O} 5$, and $\mathrm{PVY} \mathrm{Y}^{\mathrm{NA}-\mathrm{N}}$, as well as the general PVY diversity among isolates circulating in Brazilian potato, have not been studied so far.

In Brazil, more than $80 \%$ of seed potato is produced in only four states, with Minas Gerais being the largest potato-producing state, with a share of about $30 \%$ of national production (25). In order to address the diversity of PVY isolates circulating in potato in Brazil, we systematically characterized the set of 36 potato PVY isolates, mostly from seed potato fields in the Minas Gerais State of Brazil, with 3 isolates from the states of São Paulo and Paraná collected during the span of 24 years between 1985 and 2009. Because all these isolates came to the Plant Pathology Laboratory of the Federal University of Lavras in infected potato tubers submitted directly by growers for post-harvest testing, this set may be considered random and, thus, roughly representing isolates of PVY in circulation in Brazilian potato over the years. All 36 isolates were tested for their symptoms in tobacco, subjected to serological profiling using three MAbs specific to $\mathrm{PVY}^{\mathrm{O}}$ or $\mathrm{PVY}^{\mathrm{N}}$ serotypes, and molecularly typed using the standard, multiplex RT-PCR protocol of Lorenzen et al. (34). No nonrecombinant $\mathrm{PVY}^{\mathrm{N}}$ strain isolates were found among the 36 isolates in the collection, and only three nonrecombinant isolates belonging to the ordinary strain $\mathrm{PVY}^{\mathrm{O}}$ were identified (Tables 1 and 2). Interestingly, all three $\mathrm{PVY}^{\mathrm{O}}$ isolates were collected between 1985 and 1999 and no $\mathrm{PVY}^{\mathrm{O}}$ isolate was collected after 1999. The first recombinant isolate, PVY-FORTE, collected originally in 1996 from potato 'Baraka', had typical PVY ${ }^{\mathrm{NTN}}$ features (i.e., PVY ${ }^{\mathrm{N}}$ serotype, two characteristic RJs in its genome identified by RT-PCR, and induced vein necrosis in tobacco; Table 2). Four additional PVYNTN isolates (YN-IBIA, YN-SP22, YN-VELOX, and PVYN $-M G$ ) were collected between 1997 and 1999 from four different potato cultivars, suggesting the presence of PVY ${ }^{\mathrm{NTN}}$ isolates in the seed potato system in Brazil since at least 1996. Another recombinant PVY type, $\mathrm{PVY}^{\mathrm{N}: \mathrm{O} / \mathrm{N}-\mathrm{Wi}}$, was first collected later, in 2000 (isolate Y-BR2).

Two of the isolates from these early collections conducted between 1987 and 1996 (YN-UFLA\#1 and Y-BR) seem to be of an unusual PVY type, simultaneously displaying features typical for $\mathrm{PVY}^{\mathrm{NA}-\mathrm{N}}$ and $\mathrm{PVY}^{\mathrm{O}}$ (Table 2). Both isolates induced severe mosaic and crinkling symptoms in tobacco but no vein necrosis was observed, and both reacted only with MAb2 showing serotype $\mathrm{PVY}$; however, the RT-PCR pattern in the multiplex assay according to Lorenzen et al. (34) revealed a single, 328-bp amplicon char-

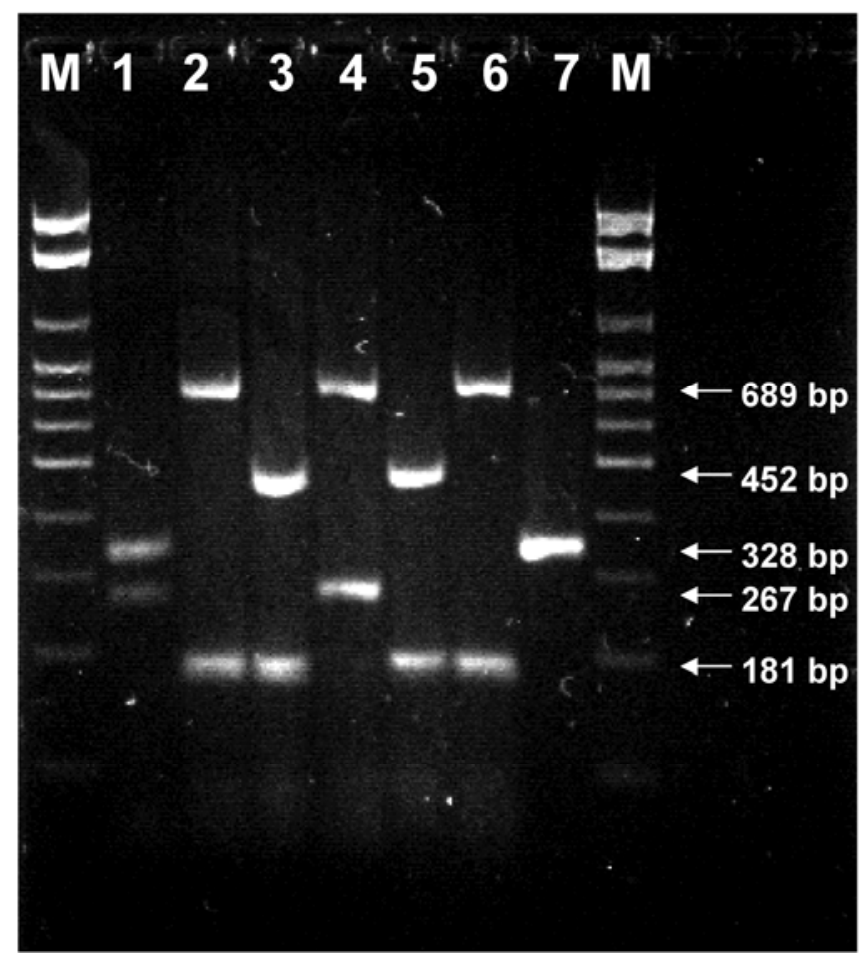

Fig. 2. Molecular typing of seven representative Brazilian Potato virus $Y(P V Y)$ isolates using multiplex reverse-transcription polymerase chain reaction $(32,34)$. Lane M, 100-bp ladder marker; lane 1, Y-BR ("unusual" PVYNA-N/O pattern); lane 2, MAF-VOY (PVYN:O-O5); lane 3, MF-AST (PVYZ-NTN); lane 4, YO-SPO8(PVYO); lane 5, CRI-AX (PVYNTN); lane 6, MAF-VIV (PVYN:O); lane 7, YN-UFLA\#1 (PVYNA-N). Positions of characteristic amplicons are listed on the right. 
acteristic of PVYNA-N . In the case of isolate Y-BR, this 328-bp amplicon was present in addition to the 267-bp amplicon characteristic of the PVY ${ }^{\mathrm{O}}$ type (Table 2). All possibilities of mixtures were tested: (i) of the seven different MAbs (including $\mathrm{PVY}^{\mathrm{N}}-, \mathrm{PVY}^{\mathrm{O}}$, and $\mathrm{PVY}^{\mathrm{O} / \mathrm{C}}$-specific MAbs) tested, only the $\mathrm{O}-$ specific antibodies reacted with both YN-UFLA\#1 and Y-BR; and (ii) a series of RT-PCR assays using the primer pairs specific to $\mathrm{PVY}^{\mathrm{NA}-\mathrm{N}}$ and $\mathrm{PVY}^{\mathrm{O}}$ types were conducted separately (not in a multiplex format), always producing the same bands amplified in a multiplex assay. Isolates YN-UFLA\#1 and Y-BR have been currently assigned an "unusual" status, and the final classification of these two isolates will await whole-genome sequencing and subsequent recombination analysis.

A large group of 25 PVY isolates collected between 2007 and 2009 contained only the $\mathrm{PVY}^{\mathrm{NTN}}$ and $\mathrm{PVY}^{\mathrm{N}: \mathrm{O} / \mathrm{N}-\mathrm{Wi}}$ recombinant strains, with PVY ${ }^{\mathrm{NTN}}$ being almost twice as frequent as the $\mathrm{PVY}^{\mathrm{N}: \mathrm{O} / \mathrm{N}-\mathrm{Wi}}$ strain (Table 2). Among the $\mathrm{PVY}^{\mathrm{N}: \mathrm{O} / \mathrm{N}-\mathrm{Wi}}$ isolates recognized only by the $\mathrm{O}-$ specific MAb, one isolate, LAV-CL, induced only mosaic and vein clearing in tobacco. Although this isolate did not induce vein necrosis in tobacco, it had a typical $\mathrm{N}: \mathrm{O} / \mathrm{N}-\mathrm{Wi}$ profile amplified in the RT-PCR multiplex assay (34), which indicated that it belonged to a relatively rare PVY strain

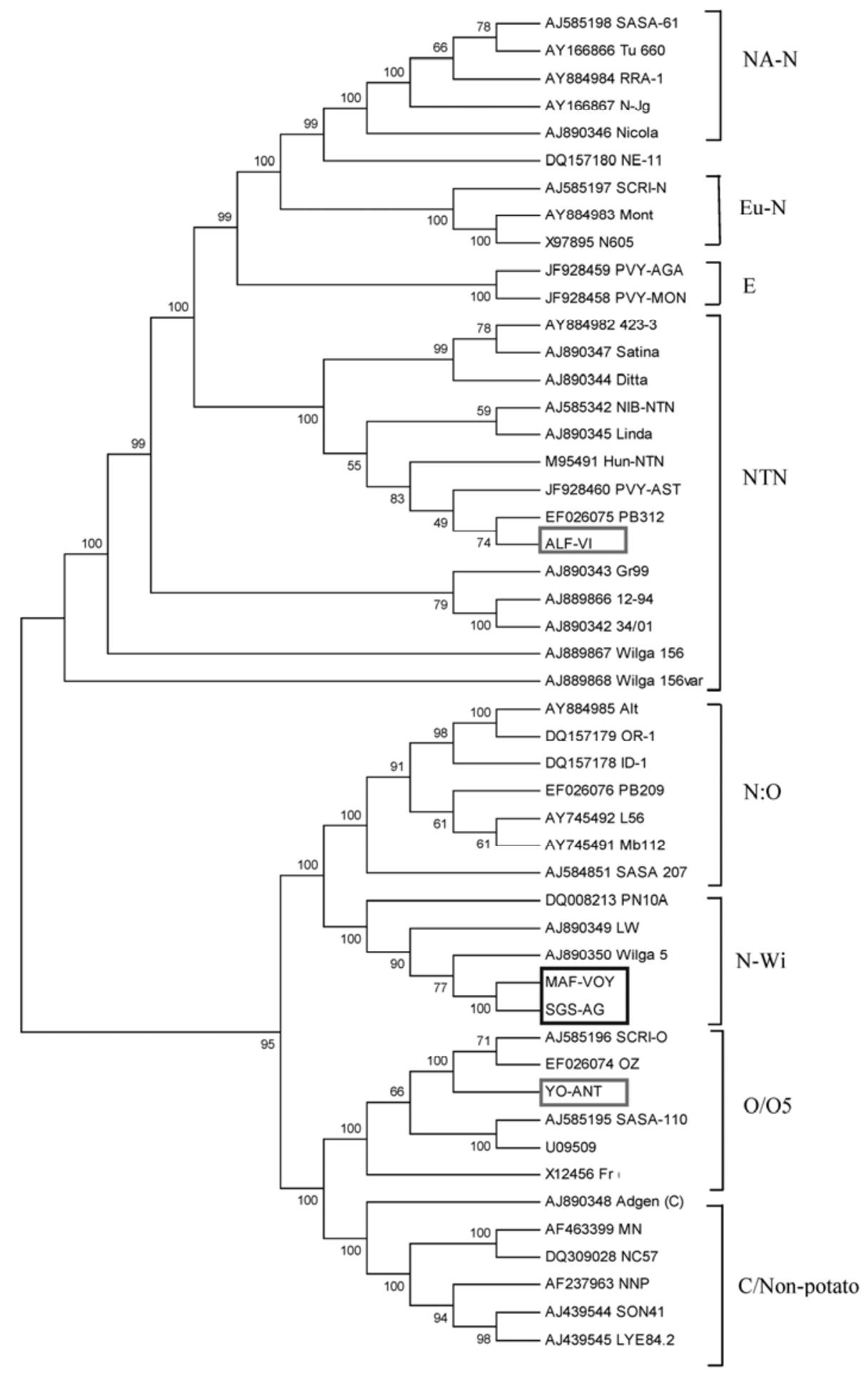

Fig. 3. Cladogram of the whole-genome nucleotide sequences of Potato virus $Y(P V Y)$ isolates. Phylogenetic trees were constructed using the neighbor-joining algorithm in the MEGA5 program. Bootstrap values are given as percentage of the 2,000 tree replicates. PVY isolate names and respective accession numbers are indicated on labels. Positions of the four Brazilian isolates sequenced in this work (ALF-VI, SGS-AG, MAF-VOY, and YO-ANT) are highlighted with squares. 
group called "N:O-minus" (22). Such an isolate could be easily misidentified as an ordinary $\mathrm{PVY}^{\mathrm{O}}$ if only biological and serological diagnostic tests had been taken into account. One recombinant isolate, MAF-VOY, displayed a typical $\mathrm{N}: \mathrm{O} / \mathrm{N}-\mathrm{Wi}$ band pattern in the multiplex RT-PCR assay (Table 2) but had a recently described serotype $\mathrm{PVY}^{\mathrm{O}}$-O5 (e.g., reacting to MAb2 and 1F5 but not to SASA-N; Table 2) (28). Up until now, this specific serotype, PVY ${ }^{\mathrm{O}}-\mathrm{O} 5$, had never been reported outside North America $(22,27,28)$. Isolate MAF-VOY is especially unusual because this is the first documented case where $\mathrm{PVY}^{\mathrm{O}}$-O5 serotype is associated with a recombinant $\mathrm{PVY}$ genome, $\mathrm{PVY} \mathrm{Y}^{\mathrm{N}: \mathrm{O} / \mathrm{N}-W i}$ in this case, whereas all previous reports found this serological marker exclusively in nonrecombinant, $\mathrm{PVY}^{\mathrm{O}}$-type genomes $(27,28)$.

Of the 21 recombinant isolates typed as PVY ${ }^{\mathrm{NTN}}, 20$ induced severe vein necrosis in tobacco. One isolate, MF-AST, did not induce vein necrosis in tobacco and, thus, was provisionally classified as PVY $^{\mathrm{Z}}$-NTN due to a typical PVY ${ }^{\mathrm{NTN}}$ band pattern in RT-PCR and a typical PVY ${ }^{\mathrm{N}}$ serotype (Table 2). This assignment is based on a recent characterization of the molecular make-up of the $\mathrm{PVY}^{\mathrm{Z}}$ strain group, which apparently comprises recombinant PVY ${ }^{N T N}$ isolates which do not induce vein necrosis in tobacco $(24,30)$. Two other PVY ${ }^{\mathrm{NTN}}$ isolates, SGS-MO and MU-AGA, shared an unusual serotype recently described for a recombinant $\mathrm{PVY}^{\mathrm{NTN}}$ isolate, PVY-AST, from Brazil (MAb2-negative/1F5-positive/SASA-Nnegative) (19), indicating that this serotype may be relatively common in the PVY isolates circulating in Brazil.

Whole-genome sequence analysis conducted on four Brazilian isolates ( $\mathrm{Y}^{\mathrm{O}}$-ANT, ALF-VI, SGS-MO, and MAF-VOY) revealed two types of recombinant PVY genomes, PVY ${ }^{\text {NTN }}$ (ALF-VI) and $\mathrm{PVY}^{\mathrm{N}-\mathrm{Wi}}$ (SGS-MO and MAF-VOY), and a nonrecombinant $\mathrm{PVY}$ genome $\left(\mathrm{Y}^{\mathrm{O}}\right.$-ANT). All four sequences clustered into corresponding phylogenetic clades on the whole-genome tree (Fig. 3), representing three PVY strain groups present in Brazil. This sequence analysis was fully consistent with RT-PCR typing performed on these isolates (Table 2). Although the whole genome of a Brazilian PVY ${ }^{\mathrm{NTN}}$ recombinant, PVY-AST, had been reported before (19), this is the first report of the whole-genome sequences for two PVY strains collected in Brazil, PVY ${ }^{\mathrm{O}}\left(\mathrm{Y}^{\mathrm{O}}-\mathrm{ANT}\right)$ and PVY ${ }^{\mathrm{N}-\mathrm{Wi}}$ (SGS$\mathrm{MO}$ and MAF-VOY). One isolate, MAF-VOY, while being typed as belonging to the $\mathrm{PVY}^{\mathrm{N}-\mathrm{Wi}}$ strain, displayed an unusual O5 serology apparently associated with a single amino acid substitution in its capsid protein, $\mathrm{R}^{98}$ to $\mathrm{Q}^{98}(28)$. These data indicate that PVY isolates circulating in Brazil often have unusual serological properties which may complicate or hamper their differentiation.

If the entire set of the PVY isolates collected over the years in Brazil and maintained at the Federal University of Lavras col-

Table 3. Comparison of the Potato virus $Y$ (PVY) strain groups and variants found in potato in Brazil (as of early 2012) with those found in potato in North America and Europe ${ }^{\mathrm{a}}$

\begin{tabular}{|c|c|c|c|}
\hline PVY strains or types & Brazil $^{b}$ & $\begin{array}{c}\text { North } \\
\text { America }^{c}\end{array}$ & Europe $^{d}$ \\
\hline $\mathrm{PVY}^{\mathrm{O}}$ & $\mathrm{Y}$ & $\mathrm{Y}$ & $\mathrm{Y}$ \\
\hline $\mathrm{PVY}^{\mathrm{O}}-\mathrm{O} 5$ & $\mathrm{~N}$ & $\mathrm{Y}$ & $\mathrm{N}$ \\
\hline $\mathrm{PVY}^{\mathrm{C}}$ & $\mathrm{N}$ & $\mathrm{N}$ & $\mathrm{Y}$ \\
\hline PVYZ & $\mathrm{Y}$ & $\mathrm{Y}$ & $\mathrm{Y}$ \\
\hline $\mathrm{PVY}^{\mathrm{N}}$ & $\mathrm{N}$ & $\mathrm{Y}$ & $\mathrm{Y}$ \\
\hline PVYE & $\mathrm{Y}$ & $\mathrm{N}$ & $\mathrm{Y}$ \\
\hline $\mathrm{PVY}^{\mathrm{N}-\mathrm{Wi} / \mathrm{N}: \mathrm{O}}$ & $\mathrm{Y}$ & $\mathrm{Y}$ & $\mathrm{Y}$ \\
\hline $\mathrm{PVY}^{\mathrm{N}-\mathrm{W} / \mathrm{N}: \mathrm{O} 5}$ & $\mathrm{Y}$ & $\mathrm{N}$ & $\mathrm{N}$ \\
\hline $\mathrm{PVY}^{\mathrm{N}-\mathrm{Wi} / \mathrm{N}: \mathrm{O}}$ (minus) $^{\mathrm{e}}$ & $\mathrm{Y}$ & Y & $\mathrm{Y}$ \\
\hline PVYNTN & $\mathrm{Y}$ & $\mathrm{Y}$ & $\mathrm{Y}$ \\
\hline $\mathrm{PVY}^{\mathrm{NA}-\mathrm{N}}$ & $\mathrm{Y}$ & Y & $\mathrm{Y}$ \\
\hline PVY-NE-11 & $\mathrm{N}$ & $\mathrm{Y}$ & $\mathrm{N}$ \\
\hline
\end{tabular}

a $\mathrm{Y}=$ this PVY strain or type has been reported and $\mathrm{N}=$ this PVY strain or type has not been reported.

${ }^{\mathrm{b}}$ References $1,18,19,45$, and this work.

${ }^{\mathrm{c}}$ References 22, 24, 27, 28, 30, 32, 33, 36, 40, and 41.

${ }^{\mathrm{d}}$ References 3-6, 10, 11, 20, 21, 26, 29, 31, 46, and 47.

e Unique to Brazil. lection (Tables 1 and 2) is analyzed from a historical perspective, we can speculate that an influx of recombinant PVY strains in the mid- to late 1990s (50) changed composition of PVY strains circulating in potato in Brazil. Currently, the PVY ${ }^{\mathrm{NTN}}$ is considered prevalent in several local Brazilian PVY populations (1); however, among the 10 isolates collected by us in 2009 , only 4 belonged to the PVY ${ }^{\mathrm{NTN}}$ recombinant strain group while the other 6 belonged to $\mathrm{PVY}^{\mathrm{N}: \mathrm{O} / \mathrm{N}-\mathrm{Wi}}$ (Table 2). That is the first time that $\mathrm{PVY} \mathrm{Y}^{\mathrm{N}-\mathrm{Wi}}$ was found more frequently than PVY ${ }^{\mathrm{NTN}}$ in potato in Brazil, although the number of samples is certainly not sufficient to formulate a definite conclusion about the current epidemiologic distribution of PVY strains in the country. This study should be considered only a preliminary indication that the PVY strains and recombinant populations in Brazil are not static and continue to evolve over time. It may seem that, for some reason, the population of PVY ${ }^{\mathrm{N}-\mathrm{Wi}}$, which has long been known to have entered the country in the mid-1990s (37-39), started to outperform PVY ${ }^{\mathrm{NTN}}$ isolates. Careful analysis of the diversity of the PVY strains and variants uncovered in this work (Table 3) suggests that the overall PVY diversity in Brazil is close to the one observed in both Europe and North America, although some of the PVY strains and types (e.g., nonrecombinant $\mathrm{PVY}^{\mathrm{N}}, \mathrm{PVY}^{\mathrm{C}}$, and $\mathrm{PVY}^{\mathrm{O}}-\mathrm{O} 5$ and recombinant $\mathrm{PVY}^{\mathrm{N}: \mathrm{O}}$ ) have yet to be found in Brazil. However, it must be pointed out that at least one unique variant, $\mathrm{PVY}^{\mathrm{N}-\mathrm{Wi}}-\mathrm{O} 5$, was found among Brazilian isolates analyzed (Tables 2 and 3) and, on the other hand, only a small number of Brazilian PVY isolates were subjected to a rigorous analysis in this work.

The introduction of recombinant strains in Brazil led to many changes in the potato production system, both seed and ware potato; it especially affected the choice of cultivars, shifting it to those less susceptible to PTNRD. One of the unintended consequences of this was the introduction and spread of 'Agata' due to its failure to show foliar and tuber symptoms when infected by the majority of PVY strains and recombinants. Although the official report of necrotic recombinant strains had been published in the mid- to late 1990 s $(37,38,49)$, these recombinant isolates could have been present in Brazil a few years before that, as exemplified by the isolate PVY-FORTE collected in 1996. The principal route of entry for all these PVY strains and recombinants into Brazil has likely been via seed potato importation, and it still is an open door for new recombinants of PVY to enter and evolve under the favorable conditions of the tropical potato production system in Brazil.

\section{Acknowledgments}

This work was supported, in part, through grants from the United States Department of Agriculture (USDA)-NIFA-NRI (number 2009-35600-05025), USDA-NIFA-SCRI (number 2009-51181-05894), the USDA Agricultural Research Service Cooperative Agreement 58-5354-7-540, and the Idaho Potato Commission. S. Galvino-Costa was a recipient of an international graduate fellowship from CNPq, Federal Government of Brazil. A. R. Figueira was supported by CNPq CAPES, Coordination for the Improvement of Higher Level or Education Personnel, and FAPEMIG, Research Support Foundation of Minas Gerais. We thank T. Meacham for help in RT-PCR assays and K. Evans for help in sequencing.

\section{Literature Cited}

1. Ávila, A. C., Melo, P. E., Leite, L. R., and Inoue-Nagata, A. K. 2009. Ocorrência de vírus em batata em sete estados do Brasil. Hortic. Bras. 27:490497.

2. Baldauf, P. M., Gray, S. M., and Perry, K. L. 2006. Biological and serological properties of Potato virus $Y$ isolates in northeastern United States potato Plant Dis. 90:559-566.

3. Barker, H., McGeachy, K. D., Toplak, N., Gruden, K., Žel, J., and Browning, I. 2009. Comparison of genome sequence of PVY isolates with biological properties. Am. J. Pot. Res. 86:227-238.

4. Beczner, L., Horvath, J., Romhanyi, I., and Forster, H. 1984. Studies on the etiology of tuber necrotic ringspot disease in potato. Potato Res. 27:339352.

5. Blanchard, A., Rolland, M., Lacroix, C., Kerlan, C., and Jacquot, J. 2008 Potato virus $Y$ : a century of evolution. Curr. Top. Virol. 7:21-32.

6. Boonham, N., Walsh, K., Preston, S., North, J., Smith, P., and Barker, I. 2002. The detection of tuber necrotic isolates of Potato virus $Y$ and the accurate discrimination of $\mathrm{PVY}^{\mathrm{O}}, \mathrm{PVY}^{\mathrm{N}}$ and $\mathrm{PVY} \mathrm{C}^{\mathrm{C}}$ strains using RT-PCR. J. Virol. Methods 102:103-112.

7. Camargos, V. N., Figueira, A. R., Gomes, E. A., Galvino, S. B. F., Gerald- 
ino, P. S., Moreira, C. N. 2008. Estudos dos isolados de PVYNTN que ocorrem no Brasil. Trop. Plant Pathol. (Suppl.) 33:297.

8. Chikh Ali, M., Maoka, T., Natsuaki, T., and Natsuaki, K. T. 2010. PVY ${ }^{\text {NTN-NW, }}$ a novel recombinant strain of Potato virus $\mathrm{Y}$ predominating in potato fields in Syria. Plant Pathol. 59:31-41.

9. Chrzanowska, M. 1991. New isolates of the necrotic strain of potato virus Y $\left(\mathrm{PVY}^{\mathrm{N}}\right.$ ) found recently in Poland. Potato Res. 34:179-182.

10. Cockerham, G. 1970. Genetical studies on resistance to potato viruses $\mathrm{X}$ and Y. Heredity 25:309-348.

11. Djilani-Khouadja, F., Glais, L., Tribodet, M., Kerlan, C., and Fakhfakh, H. 2010. Incidence of potato viruses and characterization of Potato virus $Y$ variability in late season planted potato crops in Northern Tunisia. Eur. J. Plant Pathol. 126:479-488.

12. Ellis, P., StaceSmith, R., Bowler, G., and Mackenzie, D. J. 1996. Production of monoclonal antibodies for detection and identification of strains of potato virus Y. Can. J. Plant Pathol. 18:64-70.

13. Figueira, A. R., Galvino, S. B. F., Geraldino, P. S., Rabelo Filho, F. A. C., and Camargos, V. N. 2009. Presence of PVY ${ }^{\mathrm{N}-\mathrm{Wi}}$ and NE-11 isolates of Potato virus $Y$ (PVY) in Brazil. Page 62 in: 93rd Annu. Meet. Potato Assoc. Am.

14. Figueira, A. R., Moraes, F. H. R., and Pinto, A. C. S. 1996. New PVY necrotic strain is causing great losses in Brazil. (Abstr.) Phytopathology 86:S85.

15. Figueira, A. R., and Pinto, A. C. 1995. Estirpe necrótica do vírus Y da batata em sementes importadas esta causando problemas ao bataticultor mineiro. Fitopatol. Bras. (Suppl.) 20:299.

16. Figueira, A. R., Pinto, A. C. S., and Moraes, F. H. R. 1996. Alta incidência da nova estirpe necrótica do vírus $\mathrm{Y}$ da batata esta ocorrendo em todos os estados produtores do Brasil. Fitopatol. Bras. (Suppl.) 21:432-433.

17. Figueira, A. R., Souza, P. E., Cardoso, M. R. O., Gaspar, J. O., and Pádua, J. G. 1985. Ocorrência dos vírus que infectam a batateira na Região Sul de Minas Gerais. Fitopatol. Bras. (Suppl.) 10:307.

18. Figueira, A. R., Souza, P. E., and Gaspar, J. O. 1985b. Estirpes do vírus Y da batata (PVY) detectadas em Minas Gerais. Fitopatol. Bras. 10:302.

19. Galvino-Costa, S. B. F., Figueira, A., Camargos, V. V., Geraldino, P. S., Hu, X., Nikolaeva, O. V., Kerlan, C., and Karasev, A. V. 2012. A novel type of Potato virus $Y$ recombinant genome, determined for the genetic strain PVYE. Plant Pathol. 61:388-398.

20. Glais, L., Tribodet, M., Gauthier, J. P., Astier-Manifacier, S., Robaglia, C., and Kerlan, C. 1998. RFLP mapping of the whole genome of ten viral isolates representative of different biological groups of potato virus Y. Arch. Virol. 143:2077-2091.

21. Glais, L., Tribodet, M., and Kerlan, C. 2002. Genomic variability in Potato potyvirus $\mathrm{Y}$ (PVY): evidence that PVY ${ }^{\mathrm{N}} \mathrm{W}$ and $\mathrm{PVY} \mathrm{Y}^{\mathrm{NTN}}$ variants are single or multiple recombinants between $\mathrm{PVY}^{\mathrm{O}}$ and $\mathrm{PVY}^{\mathrm{N}}$ isolates. Arch. Virol. 147:363-378

22. Gray, S. M., DeBoer, S. H., Lorenzen, J., Karasev, A. V., Whitworth, J., Nolte, P., Singh, R. P., Boucher, A., and Xu, H. 2010. Potato virus Y: a significant and evolving threat to potato crops in the United States and Canada-feature article. Plant Dis. 94:1384-1397.

23. Hu, X., Karasev, A. V., Brown, C. J., and Lorenzen, J. H. 2009. Sequence characteristics of Potato virus $Y$ recombinants. J. Gen. Virol. 90:3033-3041.

24. Hu, X., Meacham, T., Ewing, L., Gray, S. M., and Karasev, A. V. 2009. A novel recombinant strain of Potato virus $Y$ suggests a new viral genetic determinant of vein necrosis in tobacco. Virus Res. 143:68-76.

25. IBGE, Instituto Brasileiro de Geografia e Estatística. 2011. Indicadores IBGE: Estatística de Produção Agrícola, Junho de 2011. http://www.ibge. gov.br/home/estatistica/indicadores/agropecuaria/lspa/estProdAgr_201106. pdf

26. Jones, R. A. C. 1990. Strain group specific and virus specific hypersensitive reactions to infection with potyviruses in potato cultivars. Ann. Appl. Biol. 117:93-105.

27. Karasev, A. V., Hu, X., Brown, C. J., Kerlan, C., Nikolaeva, O. V., Crosslin, J. M., and Gray, S. M. 2011. Genetic diversity of the ordinary strain of Potato virus $Y$ (PVY) and origin of recombinant PVY strains. Phytopathology 101:778-785

28. Karasev, A. V., Nikolaeva, O. V., Hu, X. et al. 2010. Serological properties of ordinary and necrotic isolates of Potato virus $\mathrm{Y}$ : a case study of $\mathrm{PVY}^{\mathrm{N}}$ misidentification. Am. J. Potato. Res. 87:1-9.

29. Kerlan, C. 2006 Description of Plant Viruses: Potato virus Y. Association of Applied Biologists. http://www.dpvweb.net/dpv/showdpv.php?dpvno=414

30. Kerlan, C., Nikolaeva, O. V., Hu, X., Meacham, T., Gray, S. M., and Karasev, A. V. 2011. Identification of the molecular make-up of the Potato virus $Y$ strain $\mathrm{PVY}^{\mathrm{Z}}$ : Genetic typing of $\mathrm{PVY}^{\mathrm{Z}}-\mathrm{NTN}$. Phytopathology 101:1052-1060.

31. Kerlan, C., Tribodet, M., Glais, L., and Guillet, M. 1999 Variability of Potato virus Y in potato crops in France. J. Phytopathol. 147:643-651.

32. Lorenzen, J. H., Meacham, T., Berger, P. H., Shiel, P. J., Crosslin, J. M., Hamm, P. B., and Kopp H. 2006. Whole genome characterization of Potato virus $Y$ isolates collected in the western USA and their comparison to isolates from Europe and Canada. Arch. Virol. 151:1055-1074.

33. Lorenzen, J. H., Nolte, P., Martin, D., Pasche, J. S., and Gudmestad, N. C. 2008. NE-11 represents a new strain variant class of Potato virus $Y$. Arch. Virol. 153:517-525

34. Lorenzen, J. H., Piche, L. M., Gudmestad, N. C., Meacham, T., and Shiel, P. 2006. A multiplex PCR assay to characterize Potato virus $Y$ isolates and identify strain mixtures. Plant Dis. 90:935-940.

35. McDonald, J. G., and Kristjansson, G. T. 1993. Properties of strains of Potato virus YN in North America. Plant Dis. 77:87-89.

36. McDonald, J. G., Singh, R. P. 1996. Host range, symptomatology and serology of isolates of potato virus Y (PVY) that shared properties with both the PVYN and PVY ${ }^{\mathrm{O}}$ strain groups. Am. Potato J. 73:309-315.

37. Moraes, F. H. R., Figueira, A. R., and Santos, R. C. 1997. Caracterização da nova estirpe necrótica do vírus Y da batata. Fitopatol. Bras. (Suppl.) 22:339.

38. Moraes, F. H. R., Figueira, A. R., and Santos, R. C. 1998. Multiplicação do novo isolado do vírus $\mathrm{Y}$ da batata na cv. Achat e sua diagnose em plantas e tubérculos. Fitopatol. Bras. (Suppl.) 23:320.

39. Moraes, F. H. R., Truta, A. A. C., Figueira, A. R., and Santos, R. C. 1998. Biological and molecular properties of a new necrotic strain of potato virus Y detected in Brazil. (Abstr.) Phytopathology 88:S64.

40. Nie X., and Singh, R. P. 2003. Evolution on North American PVYNTN strains Tu 660 from local $\mathrm{PVY}^{\mathrm{N}}$ by mutation rather than recombination. Virus Genes 26:39-47.

41. Nie X., Singh, R. P., and Singh, M. 2004. Molecular and pathological characterization of N:O isolates of the Potato virus $Y$ from Manitoba, Canada. Can. J. Plant Pathol. 26:573-583.

42. Nikolaeva, O. V., Roop, D., Galvino-Costa, S. F. B., Figueira, A. R., Gray, S. M., and Karasev, A. V. 2012. Epitope mapping for monoclonal antibodies recognizing tuber necrotic strains of Potato virus $Y$. Am. J. Potato. Res. 89:121-128.

43. Nobrega, N. R., and Silberschmidt, K. 1944. Sobre uma provável variante do vírus Y da batatinha (Solanum vírus 2 , Orton) que tem a peculiaridade de provocar necroses em plantas de fumo. Arq. Inst. Biol. 15:307-333.

44. Nolte, P., Whitworth, J. L., Thomton, M. K., and McIntosh, C. S. 2004 Effect of seedborne Potato virus $Y$ on performance of Russet Burbank, Russet Norkotah and Shepody potato. Plant Dis. 88:248-252.

45. Rabelo Filho, F. A. C., Figueira, A. R., Oliveira, C. L., Carvalho, K. F., Camargos, V. N., and Galvino, S. B. 2008. Estirpes necróticas do Potato virus $Y$ (PVY) que são predominantes nos campos de batata em Minas Gerais. Trop. Plant Pathol. S297.

46. Sawazaki, H. E., Souza-Dias, J. A. C., Lorenzen, J., Jeffries, C., Módolo, D. G., and Machado, D. S. 2009. Potato virus $Y^{\mathrm{NTN}}$ : a coat and P1 protein sequences analysis of a Brazilian isolate. Potato Res. 52:379-392.

47. Schubert, J., Fomitcheva, V., Sztangret-Wis'niewska, J. 2007. Differentiation of Potato virus $Y$ strains using improved sets of diagnostic PCR-primers. J. Virol. Methods 140:66-74

48. Singh, R. P., Valkonen, J. P. T., Gray, S. M., Boonham, N., Jones, R. A. C., Kerlan, C., and Schubert, J. 2008. Discussion paper: the naming of Potato virus $Y$ strains infecting potato. Arch. Virol. 153:1-13.

49. Souza-Dias, J. A. C., Barroso, P. A. V., Miranda Filho, H. S., Hayashi, P. C., and Oliveira, A. P. 1998. Ocorrência de potyvirus associado a anéis necróticos superficiais em tubérculos de batata 'Atlantic': PVYNTN no Brasil. Summa Phytopathol. 24:74

50. Souza-Dias, J. A. C., and Tristão, J. F. 1997. Rise of PVY incidence in seedpotato regions of São Paulo State (Brazil) associated with the introduction of Atlantic potatoes. Am. Potato J. 74:469. 